\title{
PERAN GURU DALAM PROSES DIVERSI TINDAK PIDANA ANAK
}

\author{
Fidyah Faramita Utami ${ }^{1}$, Andi Intan Purnamasari ${ }^{2}$ \\ ${ }^{1}$ Program Studi Ilmu Hukum, Fakultas Hukum, Universitas Tadulako \\ ff.utami@untad.ac.id \\ ${ }^{2}$ Program Studi Ilmu Hukum, Fakultas Hukum, Universitas Tadulako \\ andi.intanpurnamasari@untad.ac.id
}

\begin{abstract}
ABSTRAK
Diversi merupakan salah satu sistem penyelesaian tindak pidana anak, yang dilakukan di luar pengadilan pidana. Sistem Peradilan Pidana Anak, merupakan lex spesialis dan satu-satunya sistem dalam hukum pidana yang menggunakan sistem diversi. Keterlibatan banyak pihak menjadi salah satu keunikan sistem ini, serupa namun tak sama, begitulah perbandingan antara sistem diversi dengan mediasi. Keterlibatan beberapa pihak inilah menjadi ciri pembeda antara diversi dengan mediasi, bila mediasi hanya melibatkan pihak-pihak yang berkonflik, diversi melibatkan bukan hanya pihak yang berkonflik namun juga melibatkan pihak lain seperti tokoh masyarakat, orang tua (anak pelaku tindak pidana), tokoh agama, guru dan aparat penegak hukum. Namun dari semua pihak yang terlibat, guru dianggap salah satu pihak yang memiliki peran besar. Sebab guru sebagai pengganti orang tua, memiliki waktu bersama anak lebih banyak dibandingkan dengan pihak-pihak lainnya. Olehnya dalam penelitian ini mengangkat isu tentang bagaimana peran guru dalam proses diversi tindak pidana anak? Tujuan penelitian untuk mengetahui sejauh mana peran seorang guru sebagai tenaga pendidik dalam penyelesaian perkara pidana melalui sistem diversi. Adapun metode penelitian dengan menggunakan sistem social jurosprudence. Dan kesimpulan pada penelitian ini, bahwa peran guru terhadap pelaksanaan diversi pada tindak pidana anak sangatlah dibutuhkan, sebab guru mampu melakukan pendekatan dengan menggunakan psikologi pendidikan melalui konteks kepribadian, intelektual, maupun emosi kejiwaan anak guna mengarahkan anak menjadi pribadi intelektual masa depan. Oleh sebab itu, undang-undang memberikan ruang terhadap guru hadir dan berperan pada proses diversi tindak pidana anak.
\end{abstract}

Kata Kunci : Guru, Diversi, Tindak Pidana dan Anak

\begin{abstract}
The The Diversion is a system for solving juvenile crimes, conducted outside of a criminal court, is a lex specialist and the only system in criminal law that uses a diversion system. The involvement of many parties is one of the uniqueness of this system, similar but not the same, that's the comparison between the diversion system and the mediation. The involvement of several parties is a distinguishing feature between diversion and mediation, if mediation only involves conflicting parties, diversion involves not only conflicting parties but also involving other parties such as community leaders, parents (children of the perpetrators of crime), religious leaders, teachers and law enforcement officials. However, from all parties involved, the teacher is considered to have a big role. Because teachers, as substitutes for parents, have more time with children than other parties. Therefore, this research raises the issue of how the teacher's role in the diversion process of child criminal acts? The research objective is to determine the extent of the role of a teacher as an educator in solving criminal cases through a diversion system. The research method uses a social jurosprudence system. And the conclusion of this study, that the role of teachers in the implementation of diversion in child crimes is very much needed, because the teacher is able to approach using educational psychology through the context of the child's personality, intellectual, and psychological emotions in order to direct the child to become a future intellectual person. Therefore, the law provides space for teachers to attend and play a role in the diversion process of child crimes.
\end{abstract}

Keywords: Teacher, Diversion, Criminal 


\section{PENDAHULUAN}

Sejak tahun 2012, sistem hukum pidana anak mengalami perubahan yang signifikan. Sistem hukum pidana anak yang sebelumnya di atur dalam KUHP, kemudian beralih dengan undang-undang nomor 3 tahun 1997 tentang Peradilan Anak, dan pada tahun 2012 diubah menjadi Undang-undang nomor 11 tahun 2012 tentang Sistem Peradilan Pidana Anak. Titik balik sistem peradilan pidana anak, adalah dengan lahirnya sistem diversi pada tahun 2012. Sebelumnya penyelesaian tindak pidana yang dilakukan oleh anak, tidak dapat diselesaikan melalui penyelesaian perkara dilur pengadilan. Semua dilakukan dalam sistem peradilan pidana.

Tujuan dari peradilan pidana anak yang memiliki sistem sendiri yakni juga dapat dilihat dalam ketentuan peraturan perundang-undangan sistem peradilan pidana anak, yaitu : SMRJJ/ The Beijing Rule, Konvensi Hak-hak Anak sistem peradilan pidana anak dapat diketahui pada UU Pengadilan Anak dan UU Perlindungan Anak. ( Setya Wahyudi, 2011)

Sebelum lahirnya Undang-Undang Sistem Peradilan Pidana Anak No. 11 Tahun 2012, pelaksanaan diversi oleh aparat penegak hukum awalnya didasari kewenangan diskresi. Menurut Robert M. Bohm, sasaran yang jelas harus tercapai dalam penerapan suatu diversi adalah menghindari anak terlibat dalam suatu proses peradilan pidana.( Robert \& Keith Haley, 2002)

Diversi sendiri merupakan bagian dari sistem Restoratif Justice. Ada beberapa prinsip dasar dari Restoratif justice terkait hubungan antara kejahatan, pelaku, korban, masyarakat dan negara. Pertama, kejahatan ditempatkan sebagai gejala yang menjadi bagian tindakan sosial dan bukan sekedar pelanggaran hukum pidana; kedua, Restoratif justice merupakan teori peradilan pidana yang fokusnya pada pandangan yang melihat bahwa kejahatan adalah sebagai tindakan oleh pelaku terhadap orang lain atau masyarakat daripada terhadap negara. Jadi lebih menekankan bagaimana hubungan dan tanggung jawab pelaku (individu) dalam menyelesaikan masalahnya dengan korban atau masyarakat. ketiga, kejahatan dipandang sebagai tindakan yang merugikan orang dan merusak hubungan sosial. Hal ini jelas berbeda dengan Hukum Pidana yang telah menarik kejahatan sebagai masalah negara, hanya negara yang berhak menghukum; keempat, munculnya ide Restoratif justice sebagai kritik atas penerapan sistem peradilan pidana dengan pemenjaraan yang dianggap tidak efektif menyelesaikan konflik sosial.

Gagasan pelibatan korban dalam proses menyelesaikan kasus pidana, yang nantinya memberikan peluang lebih besar bagi korban untuk menentukan bentukbentuk penyelesaian yang sesuai dengan kebutuhan-kebutuhan asasi korban tindak pidana, disebut peradilan restoratif (Restorative Justice). Dewasa ini peradilan restoratif telah menjadi trend global perkembangan sistem peradilan hukum pidana. Beberapa karakteristik dari program-program dan hal yang dapat ditarik dari keadilan restoratif antara lain meliputi: victim-offender Alternative dispute resolution (jalur alternatif penyelesaian kasus antara pelaku dan korban); meet discussing problems (memfasilitasi pertemuan berbagai pihak); Suport (saling menunjang); victim assistance (membantu korban); ex-offender assistance (membantu orang yang pernah melakukan kejahatan); restitution (memberi ganti rugi atau menyembuhkan); community service (pelayanan masyarakat) adalah rekondisi kepada para penderita kerugian akibat kejahatan; pelaku memiliki kesempatan untuk terlibat dalam pemulihan keadaan serta pengadilan berperan untuk menjaga terlaksanannya ketertiban dan masyarakat bertugas menjaga keadilan. (Marlina, 2009) Pada konsep restoratif inilah ditarik dalam Sistem Peradilan Khusus Anak melalui bentuk Diversi. (Natangsa Surbakti, 2014)

Pelaksanaan diversi dilatarbelakangi keinginan menghindari efek negatif terhadap jiwa dan perkembangan anak oleh keterlibatannya dengan sistem peradilan pidana. Dalam pelaksanaan diversi, berbagai pihak terlibat untuk menjadi penengah. fasilitator diversi menentukan 
hari musyawarah diversi antara semua pihak yang terlibat, dalam hal ini yaitu anak sebagai pelaku, korban (baik anak maupun orang dewasa) dan orangtua atau walinya, pembimbing kemasyarakatan, pekerja sosial profesional, perwakilan masyarakat dan pihak-pihak lain yang dipandang perlu hadir dalam proses diversi.

Pihak lain yang dimaksud di sini salah satunya adalah Guru. Namun faktanya, pada ketentuan undang-undang nomor 11 tahun 2012 tentang Sistem Peradilan Pidana Anak, dan dalam Peraturan Mahkamah Agung Nomor 4 Tahun 2014 Tentang Pedoman Pelaksanaan Diversi Dalam Sistem Peradilan Pidana Anak tidak secara signifikan menyebutkan guru sebagai salah satu pihak yang perlu hadir. Ketentuan klausul "guru" hanya masuk dalam kategori pihak-pihak lain yang dipandang perlu hadir dalam proses diversi. Dari fakta tersebut penelitian ini kemudian memproses fokuskan isu tentang peran guru dalam proses diversi tindak pidana anak. Yang tentunya penelitian ini bertujuan untuk melihat seberapa besar peran guru bertindak sebagai salah satu pihak yang dapat mempengaruhi berhasilnya sistem diversi di lakukan.

\section{METODE PENELITIAN}

Penelitian terkait isu peran guru terhadap pelaksanaan diversi ini, dilakukan dengan pendekatan social Jurisprudence. Atau Mengacu dengan judul dan perumusan masalah, maka penelitian ini menggunakan metode penelitian bersifat empiris, atau yang menurut Sudarto dapat dikategorikan sebagai penelitian hukum yuridis normatif dalam arti luas yakni Sudarto dalam Barda Nawani Arif, membagi metode Yuridis Normatif dalam dua arti Metode Yuridis dalam Arti sempit dan Metode Yuridis dalam arti Luas. Metode yuridis dalam arti sempit ialah penggunaan metode yang hanya melihat kelogisan sebuat penelitian, bahkan dapat juga dengan metode lain yang sistematis, dalam sebuah kesatuan norma. Sebaliknya apa yang ditelisik bukan hanya semata-mata melihat seperangkat norma, namun juga pada efek sosial yang dihasilkan dari pembentukan normanorma, (hukum), sehingga justru dilihat pentingnya latar belakang kemasyarakatanya, maka metode ini tidaklah kurang yuridis pula, ialah yuridis dalam arti luas. Metode yang dilakukan baik metode kepustakaan maupun melakukan wawacara bersama pihak terkait dalam sistem diversi pada Tindak Pidana Anak.

Selain itu, lokasi penelitian dilakukan di Kota Palu. Metode yang digunakan untuk mengumpulkan data ialah melalui studi kepustakaan yakni bahan hukum primer maupun bahan hukum sekunder, serta ada pula wawancara yang dilakukan langsung ke responden. Data primer hasil wawancara dan data sekunder hasil riset dokumen, kemudian dilakukan analisa data secara kualitatif, melalui langkah-langkah Pertama, sumber diperoleh melalui observasi (seleksi sumber). Kedua, dilakukan telaah khusus terhadap sumbersumber yang ada (interpretasi). Ketiga, dilakukan pengujian terhadap sumber melalui analisa. Keempat, hasil penelitian (konklusi) dirumuskan

\section{HASIL DAN PEMBAHASAN}

\section{A. Diversi dalam Sistem Peradilan Pidana Anak}

Pedoman dalam pelaksanaan diversi disebutkan bahwa konsep diversi yang dilaksanakan dalam sistem peradilan terhadap anak, merupakan sistem untuk memberikan perlindungan sebesar-besarnya bagi anak, bahkan senantiasa mempertimbangkan sebesar-besarnya kepentingan perkembangan anak, secara psikis atau mentalnya. Diversi melewati prosesbahwa anak akan diserahkan kepada orang tua baik secara formal maupun tidak formal, mediasi, musyawarah keluarga pelaku dan keluarga korban, atau bentukbentuk penyelesaian terbaik lainnya yang sesuai dengan budaya masyarakat setempat.( Momo Kelana : 2002, 111-112)

Pihak kepolisian harus mampu melaksanakan diversi di tahap awal, yang mana hal ini dapat memberi pengaruh yang besar kepada masyarakat untuk memberikan gambaran bahwa sesungguhnya tindakan pidana yang dilakukan oleh anak tidak lain merupakan proses perkembangannya yang 
menyimpang, maka dapat dikategorikan sebagai kenakalan yang dilakukan oleh anak remaja. Tindak pidana anak, merupakan bagian dari keterlibatan semua elemen masyarakat untuk sama-sama memberikan perbaikan terhadap anak tersebut melalui keterlibatan semua pihak untuk mengambil peran guna mencari solusi terbaik bagi kepentingan pihak-pihak yang menjadi korban dan juga bagi kepentingan anak sebagai pelaku.

Peraturan Mahkamah Agung (PERMA) Nomor 4 Tahun 2014 Tentang Pedoman Pelaksanaan Diversi dalam Sistem Peradilan Pidana Anak. PERMA ini dibuat dengan pertimbangan bahwa diversi merupakan proses yang harus diupayakan pada tingkat penyidikan, penuntutan, dan pemeriksaan perkara anak di pengadilan dengan mengutamakan pendekatan keadilan restoratif. Hal tersebut merupakan amanah Undang-Undang Nomor 11 Tahun 2012 Tentang Sistem Peradilan Pidana Anak. Oleh sebab itu, Mahkamah Agung selaku lembaga tertinggi dalam lingkup peradilan pidana menetapkan PERMA sebagai pedoman pelaksanaan diversi di pengadilan. Tahapan proses diversi berdasarkan PERMA tersebut dimulai dengan penunjukan Fasilitator Diversi oleh Ketua Pengadilan yang terdapat dalam Pasal 1 ayat (2). Dalam pasal tersebut yang oleh peneliti diuraikan sebagai berikut :

1) Ketentuan mengenai Fasilitator Diversi, yakni Hakim yang bertugas terhadap kasus anak yang dimaksud berdasarkan hasil penunjukan oleh Ketua Pengadilan. Kemudian hakim yang telah ditunjuk perlu menentukan hari untuk memediasi pertemuan para pihak baik korban dan orangtua atau walinya, pembimbing kemasyarakatan, pekerja sosial profesional, perwakilan masyarakat dan pihak-pihak lain yang dipandang perlu hadir dalam proses diversi. Lalu dilakukan musyawarah yang telah mana proses pelaksanaannya telah diinfokan terlebih dahulu. Tahapan tersebut terdapat dalam Pasal 5 Peraturan Mahkamah Agung Nomor 4 Tahun 2014 Tentang Pedoman Pelaksanaan Diversi Dalam Sistem Peradilan Pidana Anak. Pedoman tersebutlah yang menjadi rambu - rambu hakim fasilitator menjalankan diversi.

2) Hakdan Kewajiban Fasilitaor terhadap proses diversi juga diuraikan dalam proses diversi.

3) Dakwaan terhadap anak yang melakukan tindak pidana perlu dijelaskan dalam proses tersebut.

4) Kewajiban fasilitator antara lain : a. memberi kesempatan kepada anak agar keterangannya dapat diperdengarkan di depan semua pihak $b$. orang tua atau wali diberi kesempatan untuk mengemukakan usulan penyelesaian perkara. c. korban anak maupun pihak orang tua korban menanggapi usulan dan memberi masukan terhadap jenis putusan diversi yang akan diambil.

5) Pekerja Sosial Profesional pun dapat memberikan tanggapan masukan serta pandangan tentang jalan keluar yang akan diambil, tentunya dari prespektif sisi sosial anak sebagai pelaku.

6) Ketentuan lain, yang dapat menjadi pertimbangan bahwa fasilitator dapat melakukan pemanggilan beberapa pihak untuk menambahkan informasi agar penyelesaian secara diversi dapat terlaksana.

7) Bahkan pertemuan yang dilakukan tidak secara bersamaan (Kaukus) dapat dilakukan oleh fasilitator.

8) Fasilitator membuat sebuah putusan kesepakatan diversi yang berisi tentang hasil apa saja yang diperoleh dalam tingkatan diversi..

9) Hasil kesepakatan diversi tentu tidak boleh bertentangan dengan hukum dan norma yang berlaku, dan tetap memegang prinsip itikad baik.

Proses diversi mencapai kesepakatan dimana para pihak bersepakat damai dengan beberapa ketentuan, maka hasil kesepakatan diversi, antara lain : 1) Perdamaian dengan atau tanpa ganti kerugian; 2) Penyerahan kembali kepada orang tua atau wali; 3) Keikutsertaan dalam pendidikan, pelatihan keterampilan dan pemenuhan hak lain sesuai dengan peraturan perundang-undangan yang diselenggarakan di Lembaga Penempatan Anak Sementara (LPAS). 
Terdapat 3 (tiga) paradigma peradilan anak yang terkenal yaitu paradigma pembinaan individual, paradigma retributif, paradigma restoratif. (Marlina : 2009, 46-47) Paradigma pembinaan individual adalah penekanan pada permasalahan yang dihadapi pelaku bukan pada perbuatan atau kerugian yang diakibatkannya.

Tanggung jawab ini terletak pada tanggung jawab sistem dalam memenuhi kebutuhan pelaku. Sanksi yang diberikan kepada anak berdasarkan sudut pandang pembinaan terhadap individu anak sangat tidak masuk akal. Ketika seorang anak dijatuhi sanksi pidana, maka anak tersebut akan mendapatkan sanksi berupa pidana, tentu saja konsep pemidanaan tercapai, namun disisi lain tujuan dari pemidanaan itu sendiri tentu tidak tercapai. Sehingga yang tercapai hanyaah pemberian sanksi tetapi pemberian edukais terhadap anak tersebut tidak tercapai. Bagi anak yang melakukan tindak pidana, sanksi pidana bertujuan untuk memberikan rasa aman pada masyarakat, tentu sangat ironis, sebab anak seyogyanya merupakan bagian yang menjadi perhatian khsusu masyarakat. Bahkan orang dewasa siapapun memiliki andil dalam perkembangan anak dilingkungan sekitarnya.

Kesuksesan suatu masyarakat dalam menciptakan lingkungan yang harmonis, salah satu indikatornya adalah bagaimana masyarakat berperan dalam memperhatikan perkembangan anak. Hal ini berlaku juga bagi Guru. Seorang guru memiliki peran bukan hany amendidik namun memiliki kontribusi besar dalam pengembangan psikologi seorang anak. Maka peran guru dalam memulihkan kondisi anak dan memberikan semangat kepada anak untuk menghindari perbuatan pidana sangat besar. Semua pihak perlu berperan aktif, untuk menunjukan bentuk sanksi pembinaan apa yang dapat menjadi win win solution bagi semua pihak.

\section{B. Guru Sebagai Pahlawan Pendidikan terhadap Karakter Anak}

Pasal 27 UU No. 11 Tahun 2012 tentang Sistem Peradilan Pidana Anak, mewajibkan tugas bagi penyidik untuk mengumpulkan berbagai pandangan maupun pertimbangan saran dari pembimbing kemasyarakat, ketika ada kasus tindak pidana anak masuk dimeja penyidik. Penyidik memiliki kesempatan untuk meminta pertimbangan (dalam hal diangap perlu), dari ahli pendidikan, psikolog, psikiater, tokoh agama, pekerja sosial professional atau tenaga kesejahteraan sosial, dan tenaga ahli lainnya dalam hal melakukan pemeriksaan terhadap anak korban dan anak saksi, penyidik wajib meminta laporan sosial dari pekerja sosial profesional atau tenaga kesejahteraan sosial setelah tindak pidana dilaporkan dan diadukan.

Klausul ahli pendidikan yang di maksud adalah guru. Sebagian pandangan berpendapat bahwa, bila seorang anak telah terlibat kasus tindak pidana anak, maka orang tua dan guru dianggap tidak berhasil dalam mendidik anak tersebut, sehingga pada tahapan ini, anak yang melakukan tindak pidana atau yang berhadapan dengan hukum, tidak perlu lagi mendapat pendididkan karakter oleh seorang guru. Pandangan ini dianggap sangat keliru, sebab seorang anak kendatipun pelaku tindak pidana atau anak yang terjerat kasus hukum tetap masih memiliki masa depan, sehingga kesempatan untuk merubah keadaannya masih besar. Hal ini berdasarkan asas perlindungan kepada anak. Atas dasar perlindungan tersebut maka, diversi sebagai bentuk lain dari restoratif justice berlakukan. Inilah yang menjadikan Guru memiliki posisi penting untuk membentuk karakter anak.

Penting sekali untuk anak punya karakter bermental tangguh. Tapi pembentukan karakter anak tentunya tidak terjadi begitu saja dengan tiba-tiba, namun juga butuh bantuan orang lain. Tak hanya orang tua, guru pun memiliki wilayah yang sangat besar dalam pembentukan jati diri seorang anak. Dalam posisi anak yang memiliki kasus tindak pidana, seorang guru dapat melakukan sebuah hubungan yang dalam istilah penelitian ini di sebut istilah memanusiakan hubungan. Memanusiakan hubungan adalah salah satu cara yang bisa guru pakai untuk menuju cita-citanya, yaitu anak-anak Indonesia merdeka belajar. Dengan kata lain seorang guru dapat 
melakukan proses mengajar dengan menekankan pemahaman dari pandangan disposisi belajar anak. Lalu, penumbuhan kekuatan juga jati diri anak sebagai pelajar. Tujuannya, untuk merekatkan dan enciptakan keluwesan antara hubungan guru, murid, dan orang tua yang saling percaya, dekat dan bertumpu pada kesepakatan bersama.

Berdasarkan hasil wawancara yang dilakukan oleh peneliti dengan seorang guru Sekolah Menengah Negeri Model Madani Terpadu, ibu Sarita Ariyani,S.Pd.,M.Pd, menurut beliau :

"kita perlu menghidupkan ciri khas kepribadian yang tidak menggunakan kekerasan, bersikap kritis, saling memahami satu sama lain dan karakter positif lainnya. Nah, untuk menciptakan style anak yang seperti ini tentunya mereka perlu terbiasa dengan lingkungan gurugurunya, orang tuan dan stakeholder terakit mempraktikkan memanusiakan hubungan dalam kehidupan. Kadang, memanusiakan hubungan ini seringkali tidak terjadi di sekolah maupun di rumah. Beberapa guru masih tidak melihat bahwa memanusiakan hubungan adalah cara yang efektif. Mereka masih bertujuan gimana caranya secara kognitif anak berhasil, pandangannya masih gimana anak sukses di kertas ujian bukan sukses dalam relasi antar manusia, tiap anak punya tingkat kesiapan yang berbeda dibanding anak lain, kebanyakan yang kita apresiasi cuma anak-anak yang sudah lebih mampu atau siap, sementara anak-anak yang mungkin butuh waktu lebih lama, butuh dukungan ekstra, tidak terlalu diperhatikan malah bikin ia tinggal kelas misalnya. Karena itu, hubungan tersebut harus ada dulu. Kalau tidak, maka tentu saja anak akan sulit berprestasi, sulit punya kompetensi karena merka merasa nggak aman dan nyaman di sekolah, Jadi kalau kita melihat ada kasus kekerasan di sekolah itu karena hubungannya tidak dimanusiakan. Budaya antar pemangku kepentingan di sekolah tidak terjalin dengan utuh. Dan lagi berujung anak yang dihukum, disalahkan dan lainnya.".

Olehnya dalam memberikan perubahan terhadap seorang anak yang berhadap dengan hukum, peran guru sangat besar tentu melalui sebuah dialetika yang dikenal dengan sebutan memanusiakan hubungan. pendidikan karakter yang diimbangi dengan sistem pembelajaran baik akan efektif untuk membentuk karakter anak. Bila kemudian proses diversi berjalan dengan lancar dan terlaksana, maka tentunya setelah itu penididikan karakter terhadap anak yang berhadapan dengan hukum tersebut patut untuk menjadi hal yang diutamakan. Disinilah guru secara berkelanjutan berperan besar untuk membentuk perilaku anak bersama orang tua, bahkan guru dapat disebut sebagai pahlawan karakter anak. Namun bila diversi gagal terlaksana, atas tidak adanya kesepakatan oleh pihak yang berperkara, maka guru tetap memiliki andil besar, sebab dalam lapas anak, kehadiran seorang guru bukan hanyak berfokus pada pendidikan kognitifnya, namun justru pada pendidikan karakter anak tersebut, untuk mengembalikan kepercayaan dirinya setelah terlibat dengan kasus tindak pidana anak.

\section{Peran Psikologi Pendidikan oleh Guru dalam Terlaksananya Diversi.}

Posisi pendidikan adalah posisi yang sentral dan dan universal yang mutlak ada dan harus diperhatikan secara khusus, karena ujung tombak akan setiap kebijakan keputusan yang akan diambil suatu pribadi atau instansi akhirnya harus ditentukan kembali kepada tingkat tinggi rendahnya pengetahuan yang telah diperoleh seseorang, dan juga kepada para pendidik di mana para pendidik dituntut untuk memberikan perhatian sebesar-besarnya bagi mutu pendidikan.

Lebih lanjut juga berdasarkan Wawancara kepada Guru SMP Model Terpadu Madani Sarita Ariyani,S.Pd.,M.Pd dilakukan pada 10 Oktober 2019, Pukul 13.00 Wita di SMP Model Terpadu Madani, Palu Sulawesi Tengah menjelaskan bahwa :

"Dengan demikian ada hubungan fungsional antara dunia pendidikan dengan kebutuhan pembangunan, dan hal ini merupakan hubungan kemesraan antara dunia pendidikan dengan pembangunan di mana keduanya saling mengisi. Dalam 
UUD 1945 dengan jelas dinyatakan bahwa keberhasilan kita membangun republik ini tergantung pada kualitas pelaku pembangunan yang membangun, di mana para pembangun akan terdidik dan tertempa dari proses tempaan pabrik pendidikan".

Sehingga pendidikan wajib mengharmonisasikan antara berbagai sudut pandang untuk pemenuhan kebutuhan masa depan. Pendidikan harus berjalan efektif dan tepat guna dalam pengaplikasian materi pendidikan. Pengajar hadir dalam kegiatan mengajar sebagai seorang ahli yang berkompeten, berotoritas dan menguasai seluk-beluk pengajaran serta menguasai pengetahuan kan kemampuan atau daya serap peserta didik, karena komunikasi yang terjadi dalam interaksi dengan peserta didik cenderung didominasi oleh pola komunikasi satu arah karena pendidik tidak memiliki pengetahuan akan kemampuan dan daya serap peserta didik. (B. S. Sidjabat, $1993: 7$ )
Pengajar dituntut bukan hanya mentransferkan pelajaran kepada peserta didik, tetapi juga dituntut untuk melakukan tindakan dan cara hidup yang sesuai dengan apa yang diajarkan. (Stephen Tong, 2003 : 8)

Dari uraian diatas maka penulis merumuskan bahwa tugas psikologi pendidikan dalam proses belajar-mengajar tidak hanya mencakup peningkatan mutu belajar peserta didik dalam kaitan dengan perkembangan psikisnya namun juga mempelajari perkembangan peserta didik dalam interaksinya dengan pelajaran dan faktor-faktor yang dapat mempengaruhi pembelajaran dalam pendekatanpendekatan yang dapat mempengaruhi pembelajaran.

Peran Psikologi Pendidikan terhadap perubahan mental anak yan berhadapan dengan hukum akan memberikan dampak pada masa depan anak. Berikut diagram peran Psikologi Pendidikan :

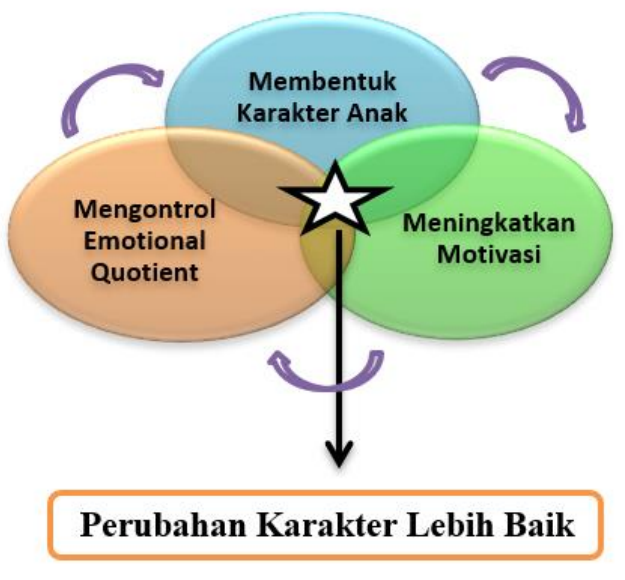

Diagram 1. Peran Psikologi Pendidikan Terhadap Anak Yang Berhadapan Dengan Hukum

Diagram tersebut memberi gambaran bahwa dalam psikologi pendidikan terdapat trilogi unsur yang dapat saling berkesinambungan dan yakni Membentuk Karakter Anak, Meningkatkan Motivasi Anak, dan Mengontrol Kecerdasan Emosional anak. Olehnya dapat diurai bahwa untuk mencapai perbaikan terhadap diri anak (ditunjukan dengan simbol bintang) adanya irisan sebagai gabungan antara 3 komponen yang lain. Dimana masing-masing komponen memiliki fungsi yang saling mendukung. Komponen pertama diuraikan bahwa Psikologi Pendidikan dapat membentuk Karakter anak sebab seorang pendidik yang telah mengetahui kepribadiannya sendiri mempunyai pemahaman yang baik untuk memberikan pengalaman belajar yang lebih bijaksana kepada anak, sehingga kendatipun seorang anak pernah menjadi anak yang berhadapan dengan hukum, namun anak tetap memiliki kepercayaan diri utnuk berubah dan menemukan jati diri 
yang lebih baik. Komponen kedua yakni meningkatkan motivasi, psikologi pendidikan dapat menemukan permasalahan dari berbagai masalah pendidikan dengan melihat pada kepribadian peserta didik yang dipengaruhi situasinya, maka dengan melihat situasi yang melatarbelakangi anak dapat melakukan tindak pidana, psikologi pendidikan dapat memberi kemampuan seorang guru untuk meningkatkan motivasi terhadap anak tersebut. Dan yang ketiga adalah mengontrol emotional quotient dimaksud bahwa Mengetahui keadaan emosi seseorag sehingga dengan mengetahui emosi tersebut seorang pendidik dapat memahami dan memperlakukakan seorang peserta didik dengan bijaksana. Emosi adalah suatu keadaan jiwa yang dapat sangat berpengaruh bagi keadaan belajar peserta didik. Jika keadaan emosinya stabil maka ia dapat belajar dengan baik, begitu juga sebaliknya.

\section{KESIMPULAN DAN SARAN}

Atas Uraian Tersebut di atas, maka penelitian ini menyimpulkan bahwa guru merupakan pihak yang memiliki peran besar dalam diversi terhadap anak sebagai pelaku terhadap peristiwa pidana. Peran tersebut diimplementasikan dalam konteks memanusiakan hubungan untuk membentuk karakter anak sebagai bentuk pencegahan agar tidak mengulangi tindakannya dan implementasi lainnya dapat melalui psikologi pendidikan dengan tiga unsur utama membentuk karakter anak, Meningkatkan Motivasi, dan Mengontrol EQ. yakni:

Saran yang diajukan oleh peneliti

1. Regulasi harus secara terperinci menjadikan guru sebagai pihak yang berkedudukan penting dalam proses diversi. Bukan hanya menyebutkan sebagai pihak-pihak lain yang dianggap penting seperti pada regulasi dalam undang-undang sistem peradilan pidana anak sekarang, sebab guru memiliki kemampuan untuk membantu anak menjadi pribadi berkarakter baik berhasil atau tidaknya proses diversi.

2. Pelatihan Diversi harus menjadi program rutin di sekolah, dimaha guru sebagai sasaran program tersebut.

\section{DAFTAR PUSTAKA}

B. S. Sidjabat. 1993. Menjadi Pendidik Profesional. Bandung : Kalam Hidup

Kitab Undang-undang Hukum Pidana (KUHP)

Kitab Undang-undang Hukum Acara Pidana (KUHAP)

Marlina. 2009. Peradilan Pidana Anak di Indonesia (Pengembangan Konsep Diversi dan Restoratif Justice). Bandung : Reflika.

Momo Kelana. 2002. Memahami UndangUndang Kepolisian (UndangUndang Nomor 2 Tahun 2002) Latar Belakang Komentar Pasal demi Pasal. Jakarta: PTIK Press.

Muhamad, Rusli. 1999. Reformasi Sistem Pemasyarakatan, (Yogyakarta : dalam Jurnal Hukum Ius Quia lustum, Nomor 1, Vol. 6).

Natangsa Surbakti. 2014. Peradilan Restoratif Dalam Bingkai Empiri, Teori dan Kebijakan, Yogyakarta : Genta Publishing

Robert \& Keith Haley. 2002. Introduction Criminal Justice. Callifornia-USA : Glencoe McGraw Hill

Rohaeti, E. 2011. Transformasi budaya melalui pembelajaran matematika bermakna di sekolah. Jurnal Pengajaran MIPA, 16(1), 139-147.

Setya Wahyudi. 2011. Implementasi Ide Diversi dalam Pembaruan Sistem Peradilan Pidana Anak di Indonesia. Yogyakarta: Genta Publishing.

Stephen Tong. 2003. Arsitek Jiwa II Surabaya : Momentum

Undang - Undang Nomor 11 tahun 2012 tentang Sistem Peradilan Pidana Anak 